\title{
Dvě knihy od T. Givóna
}

\section{T. Givón:}

\section{The Story of Zero.}

Amsterdam - Philadelphia: John Benjamins 2017. XV + $414 \mathrm{~s}$.

ISBN 978-90-272-1239-9, 99 euro

T. Givón:

\section{On Understanding Grammar. Revised edition.}

Amsterdam - Philadelphia: John Benjamins 2018. XXI + 299 s.

ISBN 978-90-272-1252-8, 99 euro

Profilovaný neofunkcionalistický lingvista T. Givón vydal loni a předloni jednu knihu novou a jednu staronovou. Chceme na ně na tomto místě ve vší stručnosti upozornit.

\section{Příběh nuly}

První kniha, ta skutečně nová, zeširoka pojednává o různých aspektech nulového výrazu v jazyce. V první části se líčí povaha nulového vyjadřování: obecněji se ukazuje jeho komunikativní přirozenost i značná rozšířenost v jazycích a zkoumají se jeho kognitivní základy, konkrétněji se pak analyzuje vznik obligatorního pronominálního vyjadřování (jako funkčního ekvivalentu vyjadřování nulového), povaha neslovesných vět a kataforická nula. $V$ druhé části knihy se potom autor z deskriptivního i explikativního hlediska zabývá souhrou mezi nulovým a explicitním vyjádřením koreference ve vztažných vedlejších větách, ve slovesném doplnění finitním i infinitním, v adverbiálních vedlejších větách či při řetězení vět.

Tato kniha vznikla vlastně nedopatřením. Jejím podnětem totiž byla mylná perspektiva jistých lingvistů, rodilých mluvčích angličtiny, kteří postulovali situaci v angličtině, často vyžadující obligatorní vyjádření toho, co se jinde vyjadřuje nulou, jako normální stav, zatímco odlišnosti od tohoto stavu považovali za potřebné nějak vysvětlit. Tomuto v jistém smyslu náhodnému vzniku knihy zjevně odpovídá i ta skutečnost, že, ač pojednávající o velkém tématu nulového výrazu, kniha nereflektuje jiné bádání o něm než to, s nímž se autor sám - náhodou - polemicky setkal. Nicméně koho lingvistický „příběh o nule“ zajímá, tomu Givónovo pojednání beze všeho doporučujeme k pozornosti. Jak je u autora obvyklé, najde v něm velké množství konkrétních lingvistických dat, podnětné obecné úvahy i různé amuzantní, ale dobře ilustrující historky.

\section{Rozumět jazyku}

Druhá kniha je staronová: je to důkladně přepracované vydání stejnojmenné knihy z roku 1979, která tehdy představovala jedno z prvních procitnutí z Chomského. Rámec osmi kapitol zůstal stejný. V úvodu se formulují obecné námitky proti chomskyánské lingvistice. Nato se obecně argumentuje pro komunikativně-diskursní definici gramatiky, což se pak v dalších kapitolách konkrétně ukazuje na př́kladu negace a pádů. Poté se v jedné kapitole ukazuje role diachronie na prŕkladu vzniku gramatiky vůbec a ve dvou kapitolách na př́lkladu 
diachronní podmíněnosti forem gramatiky zvláště. Nakonec se v závěrečné kapitole nepojednává o ničem menším než o ontologickém statusu jazyka.

Kdo četl první vydání této Givónovy knihy, ví, že je podnětná - dokonce se mi zdá, že ve své bezprostřednosti, kterou zmiňuje i sám autor v nové předmluvě (s. XIX), je i podnětnější než toto revidované vydání. V něm jednak s novými empirickými daty přibylo trochu na rozvláčnosti, jednak také autor přidal i něco kritických generalizací o strukturalismu a naopak odkazů na domnělé předchůdce své verze funkcionalistické lingvistiky, které jako jakýsi jakoby povinný, ale jen prostředně adekvátní obecný rámec nacházíme i v jiných jeho publikacích a které prozrazují, že historiografie lingvistiky není autorovi blízká disciplína. Nicméně i tak těm, kdo chtějí porozumět jazyku, nelze než četbu tohoto Givónova Coursu doporučit.

\section{Bohumil Vykypěl}

Czech Language Institute of the CAS, v. v. i.

Veveř́ 97, 602 oo Brno

Czech Republic

vykypel@iach.cz 